\section{Notice of retraction}

\section{The Editors of the Journal of Plant Research}

Published online: 7 April 2009

(C) The Botanical Society of Japan and Springer 2009

\section{Erratum to: J Plant Res (2006) 119:95-104}

\section{DOI 10.1007/s10265-005-0250-2}

The Editors of the Journal of Plant Research and the publisher hereby retract the article entitled "Analysis of the physiological mechanism of salt-tolerant transgenic rice carrying a vacuolar $\mathrm{Na}^{+} / \mathrm{H}^{+}$antiporter gene from Suaeda salsa" by Fengyun Zhao, Zenglan Wang, Quan Zhang,
Yanxiu Zhao and Hui Zhang, which appeared in J Plant Res (2006) 119:95-104, due to serious flaws with respect to scientific data, according to the "Journal of Plant Research (JPR) Ethics Investigation Committee Bylaws" of the Botanical Society of Japan.

The Editors of the Journal of Plant Research, The Botanical Society of Japan 